
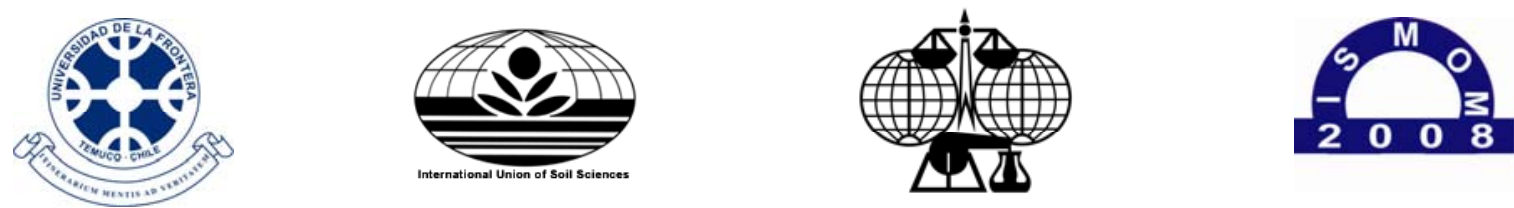

$\mathbf{5}^{\text {th }}$ International Symposium ISMOM 2008 - November $24^{\text {th }}-28^{\text {th }}, 2008$ - Pucón, Chile

Keynote papers

\title{
K-6
}

\section{Protein Adsorption at Solid Surfaces and Protein Complexation with Humic Acids}

W. Norde**, W. Tan and L. Koopal

Laboratory of Physical Chemistry and Colloid Science, Wageningen University, PO Box 8038, 6700 EK Wageningen, The Netherlands. *E-mail: Willem.Norde@wur.nl

\section{Introduction}

Proteins in soils have different origins. Most of them are exudates from animals and plants, and from dead (micro-) organisms. These proteins are substrates for enzymatically active proteins excreted by micro-organisms. Thus, proteins play an important role in biogeochemical cycles and hold potential as indicators of soil quality in ecosystem management (Burns and Dick, 2001).

Proteins have a strong affinity to bind to various soil constituents. Binding may involve changes in the protein structure and structural stability. This would affect the biological functioning, e.g., enzymatic activity, of the protein and it may also influence the availability and susceptibility of proteins for enzymatic degradation. Especially in case of pathogenic proteins this could lead to environmentally hazardous conditions (Schramm et al., 2006).

Binding of proteins to soil minerals and humic substances mediate in aggregation of these substances and therewith influences the soil structure. This is relevant for the penetration of water and air containing nutrients.

Adsorption of proteins to surfaces, including those of (models of) soil minerals has been well documented (Rigou et al., 2006; Quiquampoix and Burns, 2007). At the previous ISMOM conference (ISMOM 2004, Wuhan, China) one of us has reported on the mechanism of the adsorption of globular proteins from aqueous solution to solid surfaces. In particular, the contribution of various types of interaction to the overall adsorption affinity has been discussed. Because of the chemical and structural variation among the almost endless number of (globular) protein species, it is virtually impossible to develop a generic protein adsorption theory. Nevertheless, some principles with respect to the roles of different physical-chemical parameters have emerged, see e.g., (Norde, 1996). This resulted in the qualitative prediction scheme presented in Table1. Against this background, we discuss, in our contribution to ISMOM 2008, some experimental data on protein adsorption in model systems and examine the influence of various variables.

Besides adsorption to mineral oxides, in soils proteins interact with humic substances. However, protein - humic substance interaction has received only little attention. A few years ago, we started a study on the binding between the protein lysozyme and purified humic acid (Tan et al., 2008a; 2008b). In the second part of this paper we will summarize a few highlights of this research, emphasizing the role of electrostatic interaction in protein - humic acid complexation and in aggregation of the complexes into larger structures. 

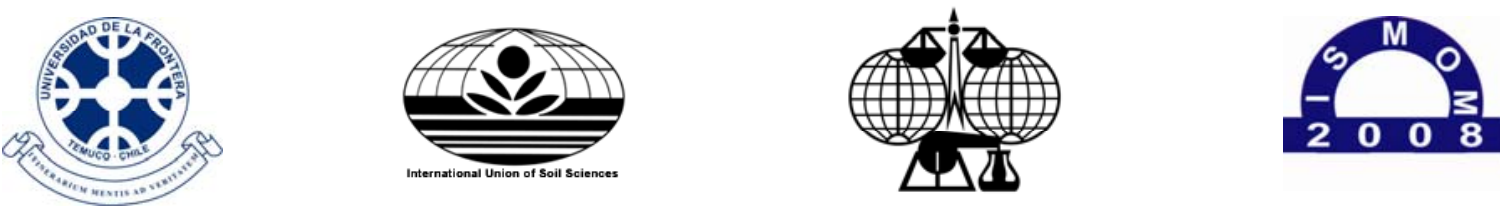

$5^{\text {th }}$ International Symposium ISMOM 2008 - November $24^{\text {th }}-28^{\text {th }}, 2008$ - Pucón, Chile

Keynote papers

Table 1. Predictive scheme of protein adsorption. Conditions at which adsorption is predicted are marked "yes" and predictions of absence of adsorption are marked "no".

\begin{tabular}{|c|c|c|c|c|c|c|}
\hline & \multirow{4}{*}{ 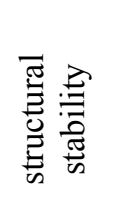 } & \multirow{4}{*}{ 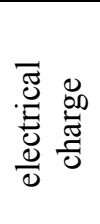 } & \multicolumn{4}{|c|}{ sorbent surface } \\
\hline & & & \multicolumn{2}{|c|}{ hydrophobic } & \multicolumn{2}{|c|}{ hydrophilic } \\
\hline & & & \multicolumn{2}{|c|}{ electrical charge } & \multicolumn{2}{|c|}{ electrical charge } \\
\hline & & & + & - & + & - \\
\hline \multirow{4}{*}{$\frac{\Xi}{\stackrel{\Xi}{0}}$} & \multirow{2}{*}{ stable } & + & Yes & yes & no & yes \\
\hline & & - & Yes & yes & yes & no \\
\hline & \multirow{2}{*}{ unstable } & + & Yes & yes & yes & yes \\
\hline & & - & Yes & yes & yes & yes \\
\hline & & & \multicolumn{2}{|c|}{$\begin{array}{l}\text { hydrophobic dehydration } \\
\text { dominates adsorption }\end{array}$} & \multicolumn{2}{|c|}{$\begin{array}{c}\text { electrical interactions or } \\
\text { structural changes in proteins } \\
\text { dominate adsorption }\end{array}$} \\
\hline
\end{tabular}

\section{Protein adsorption at surfaces of silica and hematite}

Silica and hematite are selected since they may be considered as models for mineral oxides in soil. Silica, i.e., silicium dioxide $\left(\mathrm{SiO}_{2}\right)$, is the constituent component of quartz, which occurs abundantly in sandy soils. Hematite, i.e., iron(III)oxide $\left(\alpha \mathrm{Fe}_{2} \mathrm{O}_{3}\right)$, is the dominant iron oxide mineral in (red) tropical soils, but it is less common in soils of temperate climates. As both materials are well wetted by water they are characterized as hydrophilic. Due to association or dissociation with protons the surface of $\mathrm{SiO}_{2}$ and $\alpha \mathrm{Fe}_{2} \mathrm{O}_{3}$ acquire positive or negative electrical charge, depending on the $\mathrm{pH}$ of the surroundings. Table 2 summarizes some relevant properties of the $\mathrm{SiO}_{2}$ and the $\alpha \mathrm{Fe}_{2} \mathrm{O}_{3}$ samples, that, in our study, are supplied as finely dispersed particles.

Table 2. Some properties of silica $\left(\mathrm{SiO}_{2}\right)$ and hematite $\left(\alpha \mathrm{Fe}_{2} \mathrm{O}_{3}\right)$.

\begin{tabular}{|l|c|c|}
\hline & $\mathbf{S i O}_{2}$ & $\mathbf{\alpha F e}_{2} \mathbf{O}_{3}$ \\
\hline nature of charged groups & $-\mathrm{OH}_{2}^{+} \mathbb{\circledR}-\mathrm{OH}^{\circledR}-\mathrm{O}^{-}$ & $-\mathrm{OH}_{2}^{+} \mathbb{\circledR}-\mathrm{OH}^{\circledR}-\mathrm{O}^{-}$ \\
\hline isoelectric point (pH units) & $2-3$ & $8-9$ \\
\hline water wettability & $\operatorname{good}$ & $\operatorname{good}$ \\
\hline
\end{tabular}



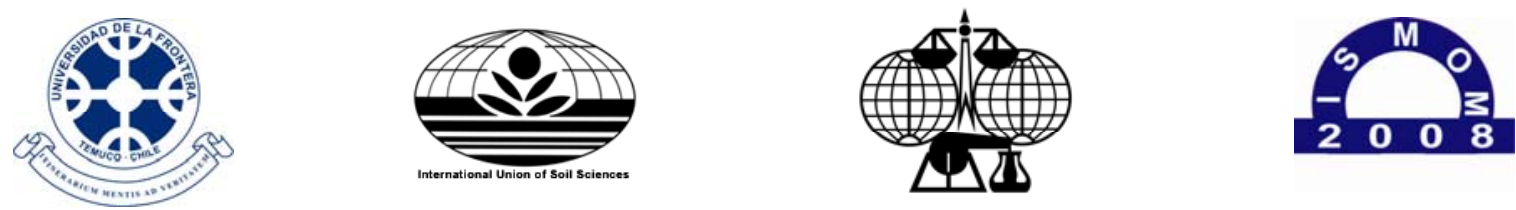

$\mathbf{5}^{\text {th }}$ International Symposium ISMOM 2008 - November $24^{\text {th }}-28^{\text {th }}, 2008$ - Pucón, Chile

Keynote papers

The proteins, discussed in this paper are, together with some of their properties, listed in Table 3.

Table 3. Some properties of the proteins used in this study.

\begin{tabular}{|c|c|c|c|c|c|}
\hline protein & source & $\begin{array}{c}\text { molar mass } \\
(\mathrm{Da})\end{array}$ & $\begin{array}{c}\text { isoelectric point } \\
(\mathrm{pH} \text { units })\end{array}$ & $\mathrm{T}_{\mathrm{d}}\left({ }^{\circ} \mathrm{C}\right)$ & $\begin{array}{c}\mathrm{D}_{\mathrm{d}} \mathrm{G} \\
\left(\mathrm{J} \mathrm{g}^{-1}\right)\end{array}$ \\
\hline LSZ & hen's egg & 14600 & 11.1 & 76 & 4.1 \\
\hline RNase & bovine pancreas & 13680 & 9.4 & 70 & 3.6 \\
\hline MGB & sperm whale & 17800 & 7.0 & & 3.0 \\
\hline$\alpha$ LA & bovine milk & 14200 & 4.3 & 63 & 1.4 \\
\hline HSA & human blood & 69400 & 4.7 & 65 & $\cdots$ \\
\hline$\alpha C T$ & bovine pancreas & 25200 & 8.1 & 59 & 2.1 \\
\hline SUB & Bacillus lentus & 27000 & 10.0 & $\cdots$ & $\cdots$ \\
\hline CUT & Aspergillus niger orizae & 20600 & 7.8 & 53 & $\cdots$ \\
\hline LAM & Pyrococcus furiosis & 30085 & 4.4 & 109 & $\cdots$ \\
\hline
\end{tabular}

LSZ: lysozyme; RNase: ribonuclease; MGB: myoglobin; $\alpha$ LA $\alpha$ Lactalbumin; HSA: human serum albumin; $\alpha$ CT: $\alpha$ chymotrypsin; SUB: subtilisin; CUT: cutinase; LAM: laminarase

Adsorption data are often presented in adsorption isotherms, where, for constant temperature, the adsorbed amount $\Gamma$ is plotted against the protein concentration $c_{p}$ in the adjacent solution, after adsorption. Adsorption isotherms for various proteins on silica and hematite are displayed in the Figures 1 and 2 (Arai and Norde, 1990; Norde and Arai, 1991). By examining the isotherms it is evident that protein adsorption is strongly influenced by electrostatic interaction. For LSZ and RNase on the hydrophilic $\alpha \mathrm{Fe}_{2} \mathrm{O}_{3}$ surface electrostatics determine whether or not adsorption occurs. However, MGB and, even more so, $\alpha \mathrm{LA}$ adsorb on $\alpha \mathrm{Fe}_{2} \mathrm{O}_{3}$ even under electrostatically adverse conditions. Apparently, for these two proteins the unfavorable effects of hydrophilic dehydration and electrostatic repulsion are outweighed by the adsorption promoting contribution related to structural rearrangements in the protein molecules that increase their conformational entropy. Adsorption of these proteins on silica confirms this conclusion. Note that the structures of MGB and $\alpha$ LA are less stable ("soft" proteins) than those of LSZ and RNase ("hard" proteins). Moreover, for the silica surface the initial part of the adsorption isotherms (reflecting the affinity between the protein and the sorbent surface) and the plateau-values of the isotherms scale with electrostatic attraction (Figure 2, left panel); the same applies to the rate of adsorption (Figure 2, right panel).

Many protein adsorption studies included bovine or human serum albumin (BSA and HSA, respectively). The globular structures of BSA and HSA are relatively unstable and, hence, they show a strong adaptability towards structural changes upon adsorption. Therefore, the profile of the plateau-value $\Gamma_{\mathrm{p}}$ of the adsorption isotherm of these proteins (and many others) as a function of $\mathrm{pH}$ 

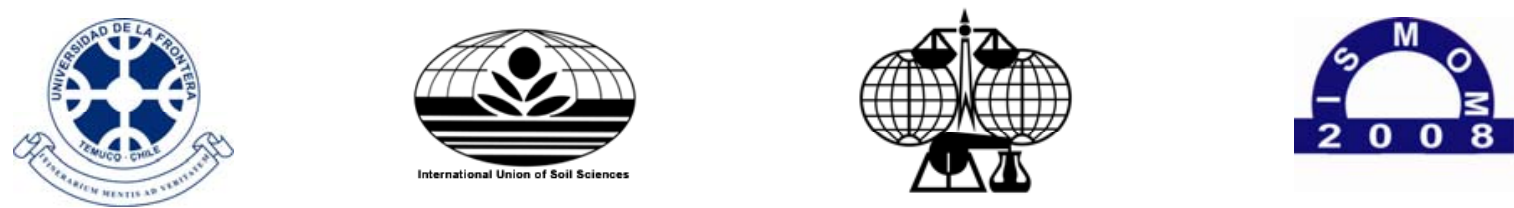

$5^{\text {th }}$ International Symposium ISMOM 2008 - November $24^{\text {th }}-28^{\text {th }}, 2008$ - Pucón, Chile

Keynote papers

is similar for different sorbent surfaces (Morrissey and Stromberg, 1974; Bagchi and Birnbaum, 1981; Haynes and Norde, 1994)
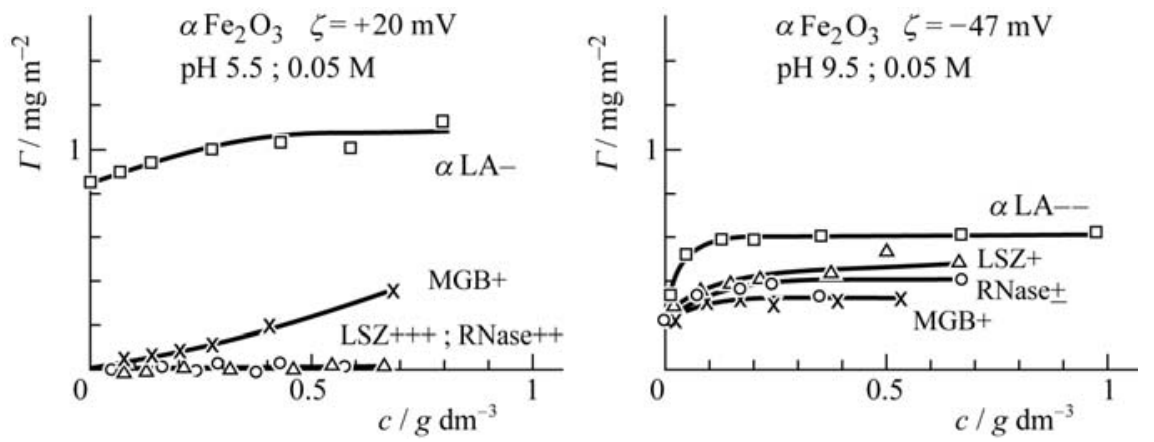

Figure 1. Adsorption isotherms for various proteins at $\alpha \mathrm{Fe}_{2} \mathrm{O}_{3}$ surfaces. $\mathrm{T}=25^{\circ} \mathrm{C}$. (Redrawn from reference 8)

It suggests that plateau-adsorption is related to protein characteristics rather than to proteinsorbent interactions. Figure 3 gives $\Gamma_{\mathrm{p}}(\mathrm{pH})$ for HSA on $\alpha \mathrm{Fe}_{2} \mathrm{O}_{3}$ at various ionic strengths (Koutsoukos et al., 1983). At all ionic strengths $\Gamma_{\mathrm{p}}(\mathrm{pH})$ passes through a maximum around $\mathrm{pH} 5.1$, which is slightly beyond the isoelectric point (iep) of HSA. Maximum adsorption in the isoelectric region is quite general for proteins. It may be explained by progressive structural rearrangements in the adsorbing molecules when the $\mathrm{pH}$ is further away from the iep and stronger intramolecular electrostatic repulsion weakens the protein structure stability. Furthermore, intermolecular repulsion between adsorbed charged protein molecules may contribute to lower adsorbed amounts per unit area of sorbent surface.
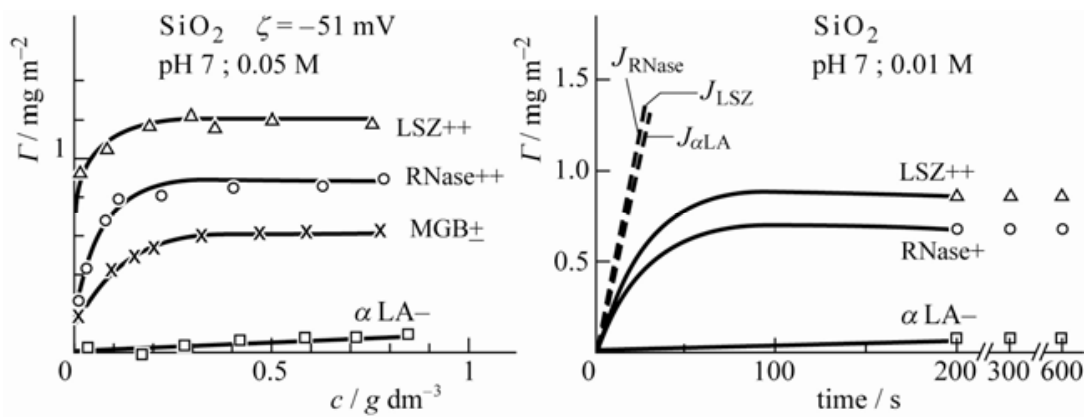

Figure 2. Adsorption isotherms (left) and adsorption kinetics (right) for various proteins at $\mathrm{SiO}_{2}$ surfaces. $\mathrm{T}=$ $25^{\circ} \mathrm{C}$. (Redrawn from references 8 and 9) 

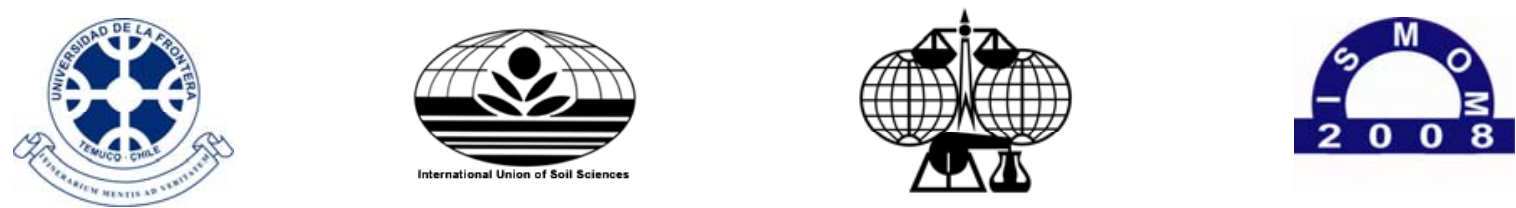

$\mathbf{5}^{\text {th }}$ International Symposium ISMOM 2008 - November $24^{\text {th }}-28^{\text {th }}, 2008$ - Pucón, Chile

Keynote papers

Increasing the ionic strength reduces intra- and intermolecular electrostatic interaction and, hence, result in a less pronounced $\Gamma_{\mathrm{p}}(\mathrm{pH})$ profile. However, the role of low-molecular-weight electrolyte, i.e., small ions, is more complicated. Simultaneously with protein adsorption ions are incorporated in (or expelled from) the contact region between the protein and the sorbent surface to prevent development of a too high charge density in that non-aqueous, low dielectric, region (van Dulm et al., 1981). The corresponding charge density effect $\Delta_{\text {ads }} \sigma$ may be derived from comparing the electrokinetic surface charge densities $\sigma_{\mathrm{ek}}$ of the species before and after adsorption. In Figure 4 $\Delta_{\text {ads }} \sigma$ is plotted for HSA adsorption on $\alpha \mathrm{Fe}_{2} \mathrm{O}_{3}$, as a function of surface coverage, $\Gamma / \Gamma_{\mathrm{p}}$, and for different $\mathrm{pH}$-values. $\Delta_{\mathrm{ads}} \sigma$ varies linearly with $\Gamma / \Gamma_{\mathrm{p}}$, meaning that the charge uptake is proportional to the number of adsorbing protein molecules. The sign of $\Delta_{\mathrm{ads}} \sigma$ is as expected: negative at low $\mathrm{pH}$, where both the protein and the sorbent are positive, and gradually more positive with increasing $\mathrm{pH}$, i.e., when the interacting species become more negatively charged.

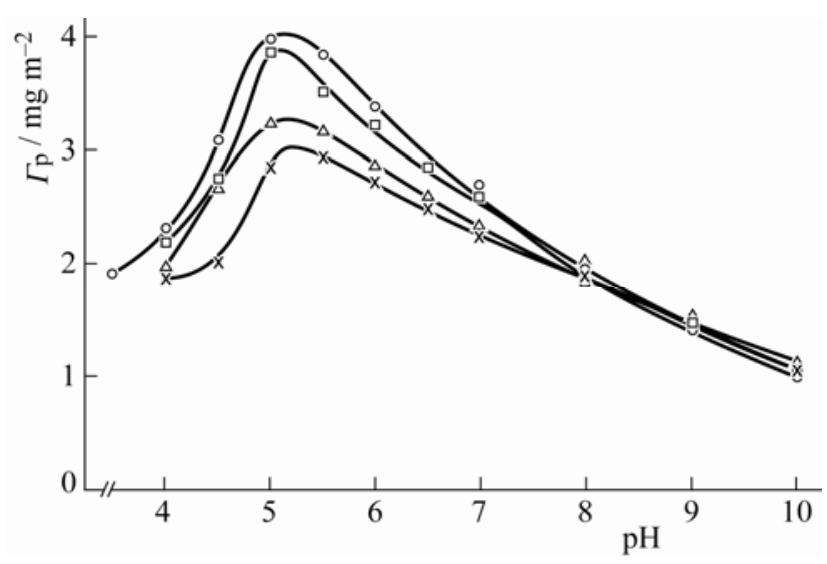

Figure 3. Influence of the $\mathrm{pH}$ on the plateau-adsorption of $\mathrm{HSA}$ on $\alpha \mathrm{Fe}_{2} \mathrm{O}_{3} \cdot \mathrm{T}=25^{\circ} \mathrm{C}$. Ionic strengths $\left(\mathrm{KNO}_{3}\right)$ $0.001 \mathrm{M}(\mathrm{\circ}) ; 0.005 \mathrm{M}(\square) ; 0.010 \mathrm{M}(\Delta) ; ; 0.015 \mathrm{M}(\mathrm{x})$. (From reference 10, with permission)

At this point a few remarks on the reversibility of protein adsorption are made. (a) Protein adsorption is highly irreversible towards changes in protein concentration in solution. In other words, only a minor fraction, if any at all, of the adsorbed proteins can be removed from the surface by rinsing with solvent. (b) Proteins adsorb semi-reversible with respect to variation in $\mathrm{pH}$ and ionic strength, that is, changing the $\mathrm{pH}$ or ionic strength may result in additional adsorption, but it does not induce considerable desorption.

Structural changes in protein molecules, having direct consequences for their biological functioning, is the most intriguing and challenging aspect of protein adsorption, both from a theoretical and practical point of view. In Figure 5 information on the influence of adsorption on the structure and activity of a number of proteins is collected (Norde and Zoungrana, 1998; Maste et al., 1995 and 1996; Koutsopoulos et al., 2005). Silica was chosen as the sorbent material because a suspension of ultra-fine particles of this material allows circular dichroism (CD) spectroscopy to be 

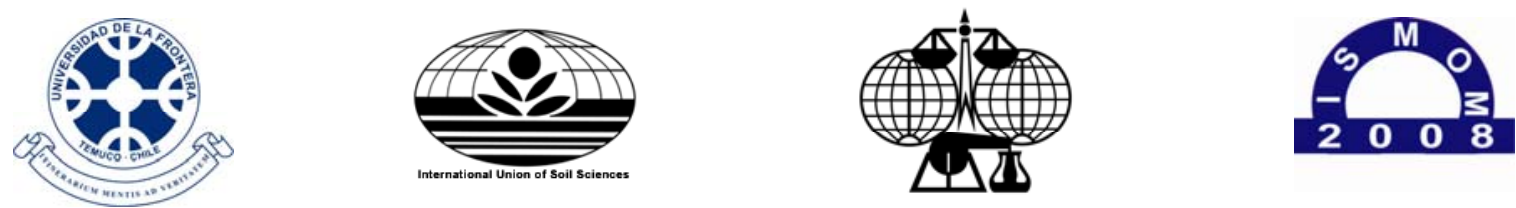

$\mathbf{5}^{\text {th }}$ International Symposium ISMOM 2008 - November $24^{\text {th }}-28^{\text {th }}, 2008$ - Pucón, Chile

Keynote papers

used to probe the secondary structure of adsorbed proteins. This is not possible with $\alpha \mathrm{Fe}_{2} \mathrm{O}_{3}$ dispersions. $\alpha$ chymotrypsin $(\alpha \mathrm{CT})$, subtilisin (SUB) and cutinase (CUT) are mesophilic proteins, i.e., they are biologically active at moderate temperatures. Laminarase (LAM) is a hyperthermophilic protein, being active in hot environments as subterranean geothermally heated biotopes, and in hot outflows from industrial plants. The denaturation temperature $T_{\mathrm{d}}$ of LAM is therefore extraordinary high.

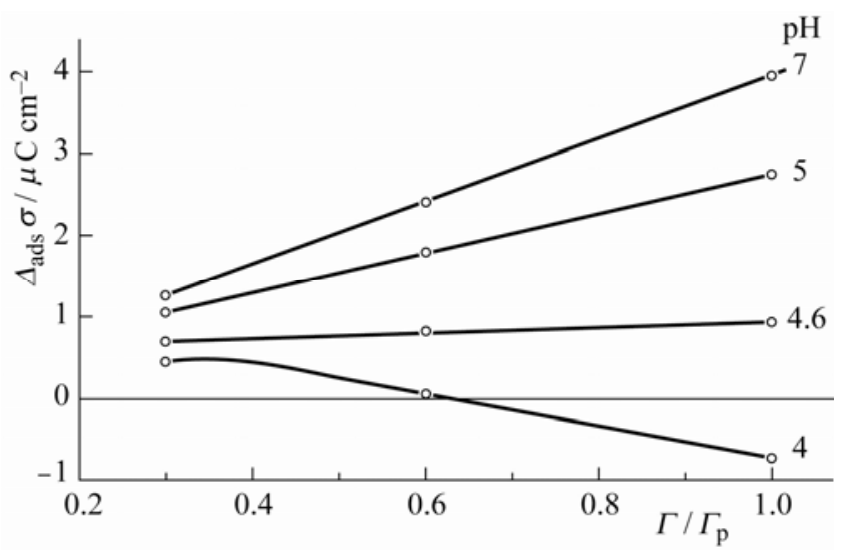

Figure 4. Charge regulation by low-molecular-weight ions during adsorption of $\mathrm{HSA}$ at $\alpha \mathrm{Fe}_{2} \mathrm{O}_{3} . \mathrm{T}=25^{\circ} \mathrm{C}$; $0.01 \mathrm{M} \mathrm{KNO}_{3}$. (Redrawn from reference 10)

At the experimental conditions $\alpha \mathrm{CT}$ and SUB are positively charged and, hence, electrostatically attracted to the negatively charged silica surface. The CD spectra of the proteins shift, although not drastically, as a result of adsorption, indicating a change in the ratio ordered/unordered structure along the polypeptide chain of the protein. For both proteins the fraction of ordered structure is lower in the adsorbed state. CUT and LAM are electrostatically repelled from the silica. The ordered structure (mainly $\alpha$-helix) of cutinase is very strongly suppressed by adsorption. The ensuing gain in conformational entropy supposedly is the driving force for the protein to adsorb at the silica surface. LAM, as a hyperthermophilic protein having peculiar structural features $[18,19]$, does adsorb at the electrostatically unfavorable, hydrophilic silica surface without detectable change in secondary structure and, hence, without significant increase of its conformational entropy. Therewith, the adsorption behavior of this peculiar protein does not fit in the predictive scheme given in Table 1. In this context, it should be mentioned that the adsorption isotherm reflects very low affinity between LAM and silica.

It is remarkable, especially for those proteins that have undergone adsorption-induced structural rearrangements, that the same denaturation temperatures $T_{\mathrm{d}}$ are detected for the adsorbed and dissolved states. However, the enthalpy of denaturation $\Delta_{\mathrm{d}} H$, expressed per unit mass of protein, is lower for the adsorbed proteins (except for LAM). The reduction of $\Delta_{\mathrm{d}} H$ resulting from adsorption correlates with the extent of structural changes revealed by the CD spectra. A decreased enthalpy 

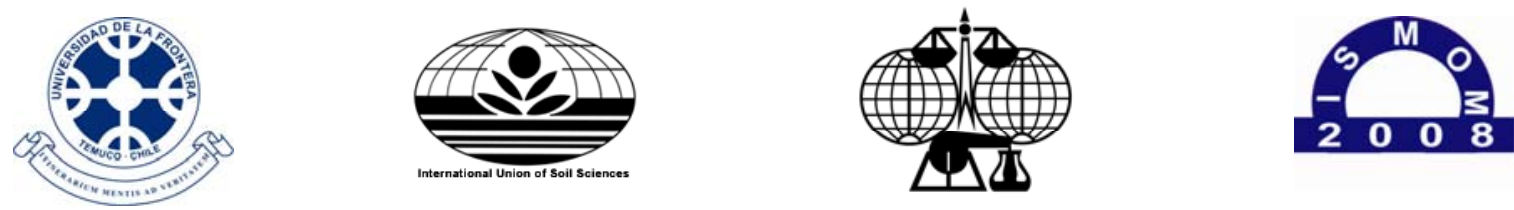

$5^{\text {th }}$ International Symposium ISMOM 2008 - November $24^{\text {th }}-28^{\text {th }}, 2008$ - Pucón, Chile

Keynote papers

change at an unaltered denaturation temperature points to a structurally heterogeneous population of adsorbed protein molecules, i.e., a fraction of the adsorbed molecules exists in a native-like structure (as in solution), whereas the remainder is in one or more adsorption-induced perturbed states (Norde and Zoungrana, 1998).

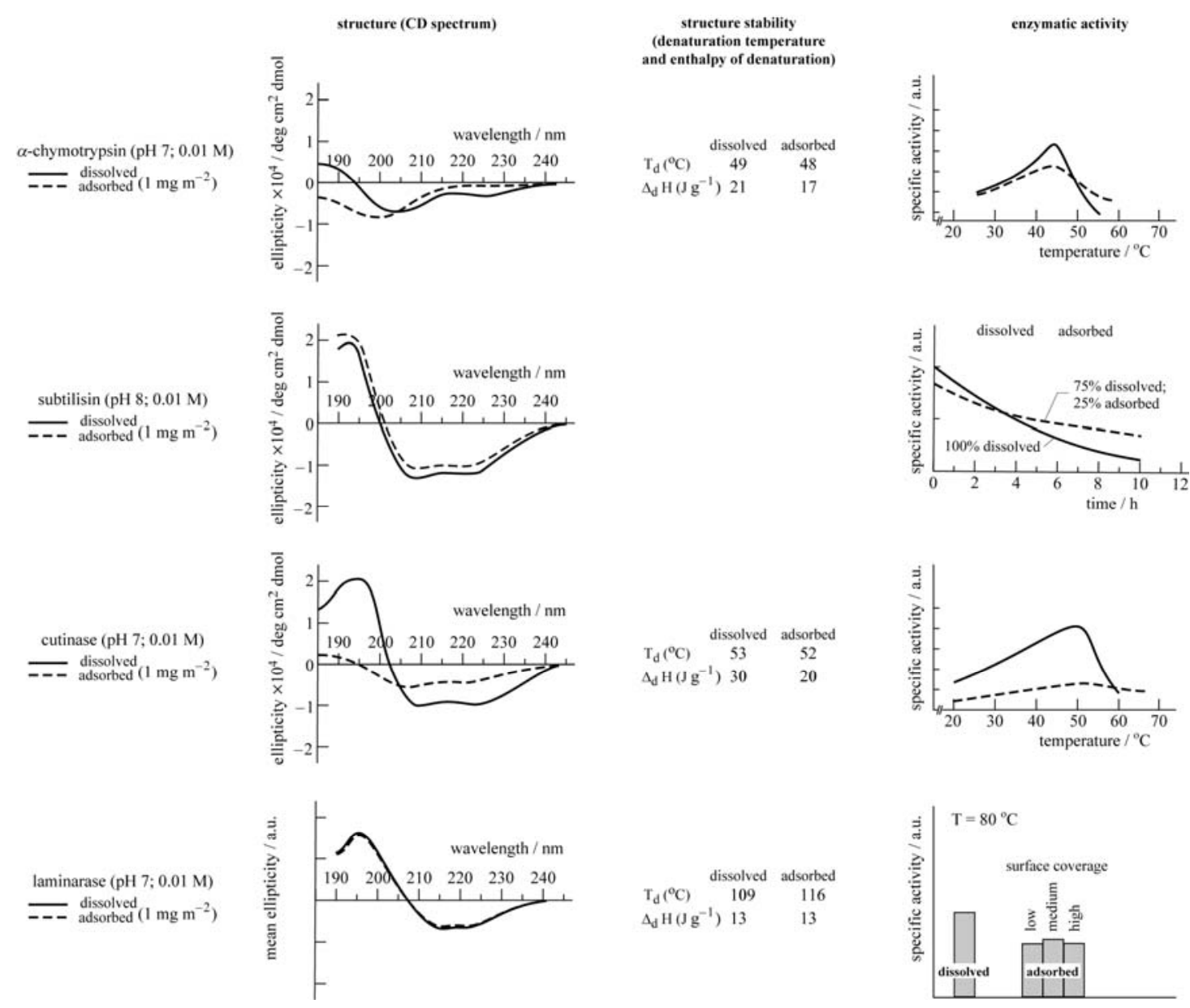

Figure 5. Effect of adsorption on the structure, structural stability and biological activity of various proteins. (Data collected from Norde and Zoungrana, 1998; Maste et al., 1995 and 1996; Koutsopoulos et al., 2005)

The impact of protein adsorption on the activity of these enzymes is more or less in line with their structural alterations. First, it is noted that in the activity assays of $\alpha C T$, SUB and CUT relatively small substrate molecules were used, whereas the activity of LAM was determined using the polysaccharide laminarin. Hence, substrate inaccessibility of the protein's active site due to 

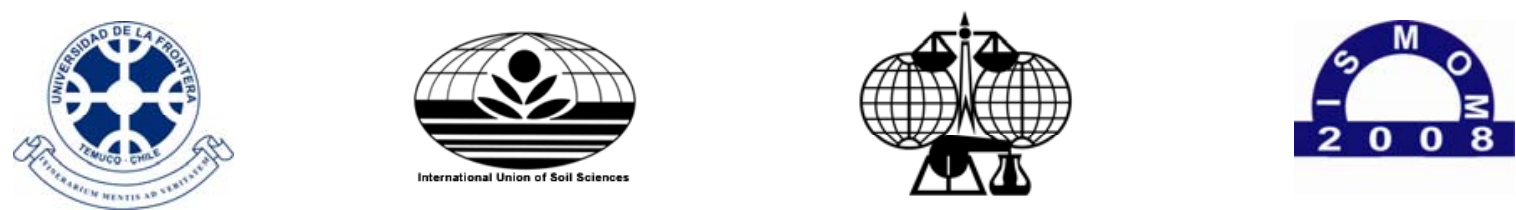

$\mathbf{5}^{\text {th }}$ International Symposium ISMOM 2008 - November $24^{\text {th }}-28^{\text {th }}, 2008$ - Pucón, Chile

Keynote papers

unfavorable orientation and crowding of the adsorbed molecules at the sorbent surface is expected to be higher for LAM than for the other proteins. Thus, the activity activity drop of LAM, by about $50 \%$, may be attributed to random orientation of the adsorbed molecules, such that half of the molecules adsorb with their active site down towards the surface rendering them inaccessible for the polymeric substrate. Another interesting feature is observed for $\alpha \mathrm{CT}$ and CUT: the specific enzymatic activity is much less sensitive to temperature variation, so that at elevated temperatures $\left(>55^{\circ} \mathrm{C}\right)$ the specific activity in the adsorbed state may be higher than in solution. Finally, it is observed for SUB that adsorption protects the enzyme against proteolytic attack, a feature that may apply to other proteins as well.

\section{Protein complexation with humic acids}

As a model for humic substances in soil purified Aldrich humic acid (PAHA) is chosen (Vermeer et al., 1998). The binding of ions and surfactants to PAHA has shown to be similar to that to other humic acids (Milne et al., 2003, Ishiguro et al., 2007), but for protein binding such comparisons have not been made yet. The molar mass of PAHA is around $20 \mathrm{kDa}$. PAHA is an anionic polyelectrolyte, mainly due to dissociation of its carboxyl groups. The chemical structure of humic acid, according to Stevenson (Stevenson, 1994), is given in Figure 6. Lysozyme (LSZ) from hen's egg (see Table 2) was selected for studying binding to PAHA. Over a wide pH range, i.e., $\mathrm{pH}<10.5$, LSZ is positively charged. The charges of PAHA and LSZ, as a function of $\mathrm{pH}$, are given in Figure 7 for various ionic strengths. Upon adding PAHA and LSZ to each other they form a complex.

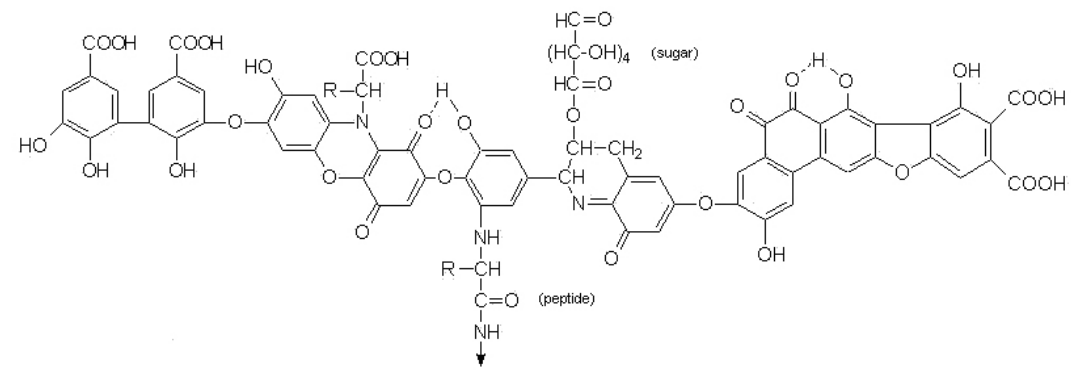

Figure 6. Model of the chemical structure of humic acid.

Complex formation is mainly driven by electrostatic attraction between the oppositely charged components. Figure 8 shows the amounts of PAHA needed to completely neutralize different amounts of LSZ (i.e., forming an isoelectric complex), at $\mathrm{pH}$ 5. The required amount of PAHA is larger at higher $\mathrm{KCl}$ concentration. This is due to an increased cation $\left(\mathrm{K}^{+}\right)$binding at the negative PAHA. The mass ratio PAHA/LSZ $\left(\equiv \mathrm{m} / \mathrm{m}_{+}\right)$in the isoelectric complex is reflected by the (constant) slope of the curves in Figure 8. The very small intercept at the PAHA-axis indicates that complexation between PAHA and LSZ occurs with high affinity. The isoelectric complexes are not reversible structures. Their composition depends on the path of formation, i.e., addition of PAHA to LSZ or LSZ to PAHA, as shown in Figure 8 (right panel). The different compositions involve 

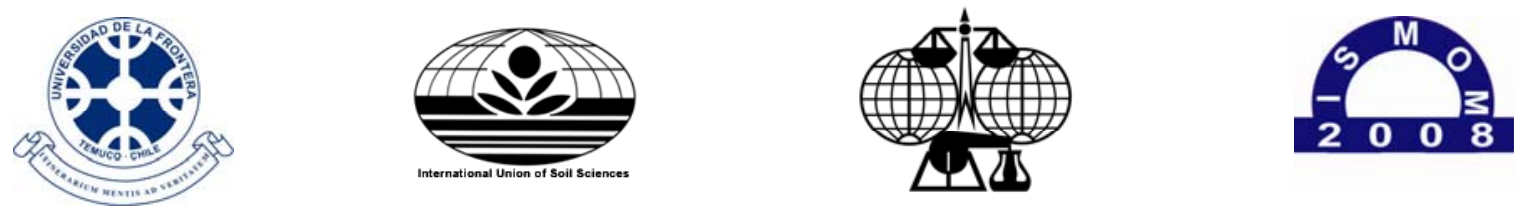

$\mathbf{5}^{\text {th }}$ International Symposium ISMOM 2008 - November $24^{\text {th }}-28^{\text {th }}, 2008$ - Pucón, Chile

Keynote papers

different structural stabilities of the neutral complexes: the complexes resulting from PAHA titrated by LSZ aggregate and precipitate after a few hours, but LSZ titrated by PAHA did not lead to complex aggregation over a prolonged period of time.
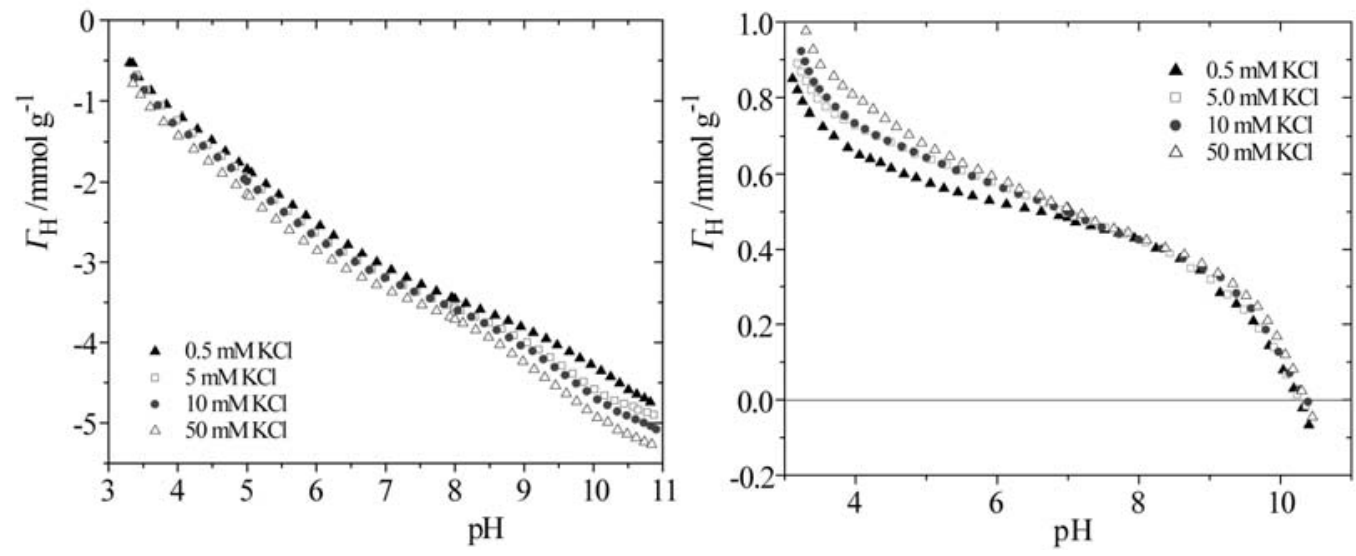

Figure 7. Proton binding on PAHA (left) and on LSZ (right) as a function of pH. (Redrawn from reference 6)
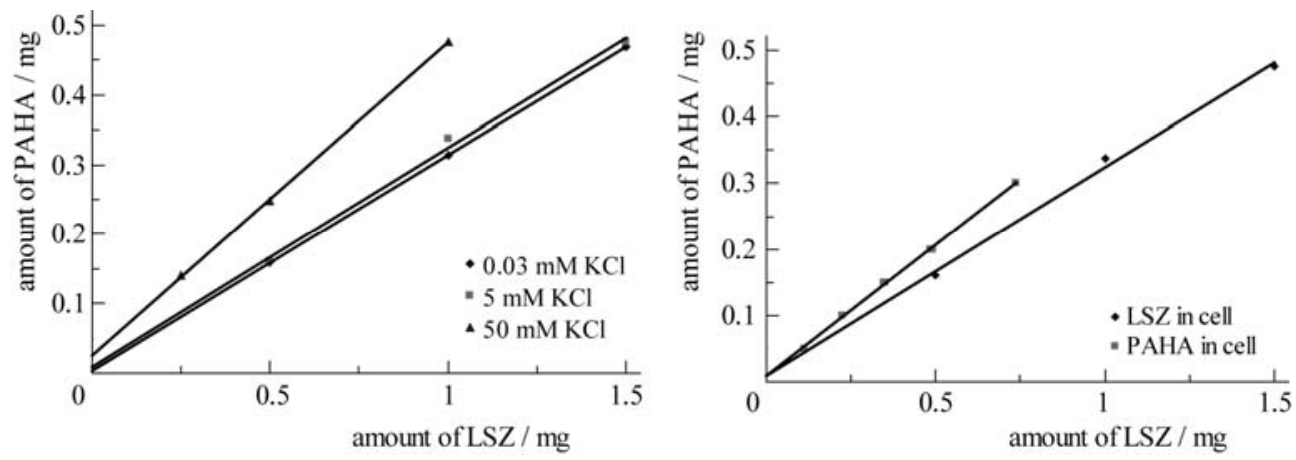

Figure 8. Amount of PAHA required to reach LSZ the isoelectric point of the LSZ-PAHA complex at pH5 at different ionic strengths (left) and for different sequences of adding the components to each other (right). (Redrawn from reference 6)

The size of the complexes was derived from dynamic light scattering, DLS, experiments. Figure 9 displays the hydrodynamic radius $R_{\mathrm{h}}$ of the complex, as a function of $\mathrm{m} / \mathrm{m}_{+}$, at $\mathrm{pH} 5$ and different ionic strengths. Clearly, complexes aggregate to larger structures when the iep is approached. The $\mathrm{m} / \mathrm{m}_{+}$dependency of $R_{\mathrm{h}}$ is less pronounced at higher ionic strength, where electrostatic repulsion 

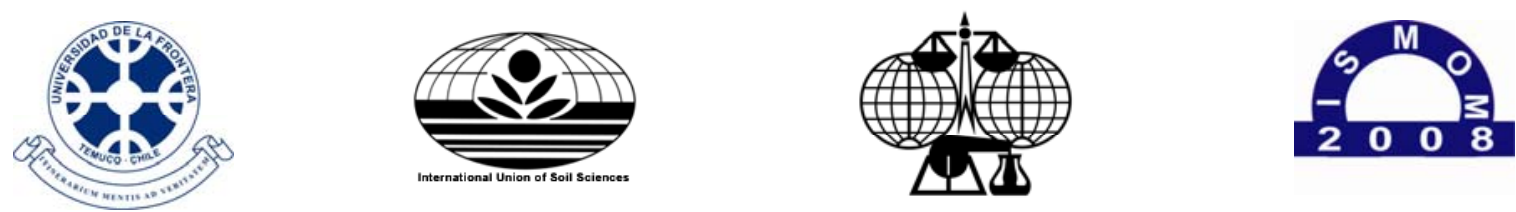

$\mathbf{5}^{\text {th }}$ International Symposium ISMOM 2008 - November $24^{\text {th }}-28^{\text {th }}, 2008$ - Pucón, Chile

Keynote papers

between the charged complexes is reduced. The a-symmetry of the $R_{\mathrm{h}}\left(\mathrm{m} / \mathrm{m}_{+}\right)$curves implies that at equal absolute charge complexes aggregate into clusters of different sizes.

The calorimetrically established enthalpy ( $\approx$ energy) of complexation, where, at $\mathrm{pH} 5$, PAHA is added to LSZ is shown in Figure 10. The negative enthalpy change is in line with favorable electrostatic interaction and this is corroborated by the reduced enthalpy change in a medium of higher salt concentration, where electrostatic interactions are screened. The first molecules of PAHA added bind to the energetically most favorable sites on LSZ. When approaching the iep of the complex, and beyond, the enthalpy effect is essentially zero. It implies that the binding is driven by an increase in entropy, which may (partly) be due to dehydration of hydrophobic patches of the PAHA and/or LSZ molecules. The $R_{\mathrm{h}}$-data (Figure 9) show that overcompensation of charge induces fragmentation of the aggregates. This as well increases the entropy of the system. Experimental results for PAHA-LSZ interaction are, mutatis mutandis, similar to those reported for pH $5[6,7]$.

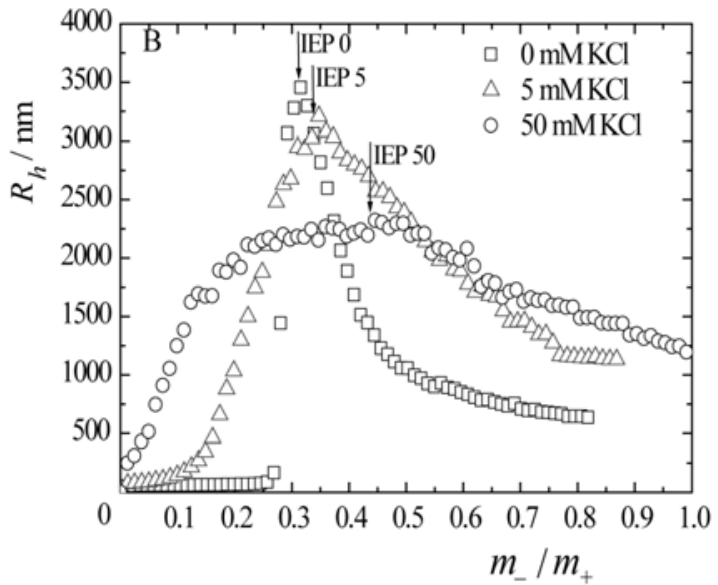

Figure 9. Hydrodynamic radius of PAHA-LSZ at $\mathrm{pH} 5$.

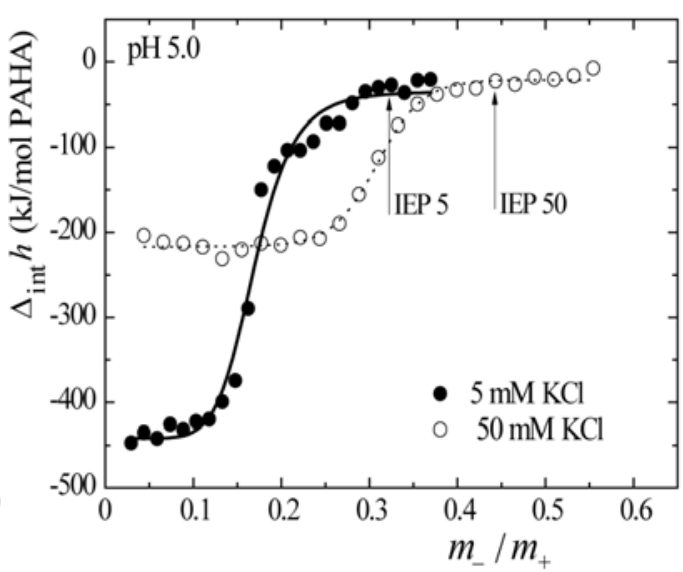

Figure 10. Enthalpy of interaction between complexes PAHA and LSZ at $\mathrm{pH} 5$.

The arrows point to the isoelectric points of the complexes. (Redrawn from reference 7)

In summary, the anionic PAHA and cationic LSZ complex with high affinity and, especially at and around the isoelectric state of the complex aggregates are formed. The features of this system are also expected to occur for other humic acid - cationic proteins. Moreover, since the driving force for the PAHA-LSZ interaction was found to be not only of electrostatic nature, negatively charged humic substances are expected to bind to some extent with negatively charged proteins as well. Complexation with humic substances probably influences the biological activity of the protein. Further, interaction between humic acid-protein complexes and mineral surfaces in the soil may lead to adsorption phenomena different from those observed when only humic acid or protein is present. 

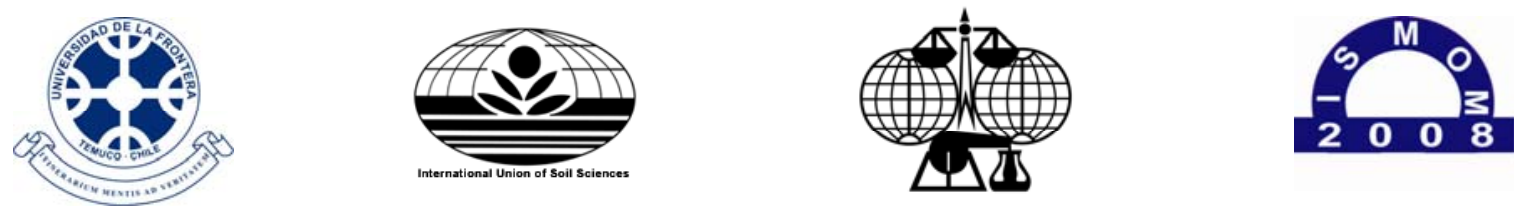

$5^{\text {th }}$ International Symposium ISMOM 2008 - November $24^{\text {th }}-28^{\text {th }}, 2008$ - Pucón, Chile

\section{Keynote papers}

Keywords: Proteins; solid surfaces; humic acids.

\section{References}

R.G. Burns and R.P. Dick. (2001). In: Marcel Dekker. Enzymes in the environment: ecology, activity and application. P.T. Schramm, C.J. Johnson, D. McKenzie, J.M. Aiken and J.A. Pedersen. (2006). Rev. Mineral Geol. 64: 135-152. P. Rigou, H. Rezai, J. Grosclaude, S. Staunton and H. Quiquampoix. (2006). Environ. Sci. Technol. 40: 1497-1503.

H. Quiquampoix and RG. Burns. (2007). Elements 3: 401-406.

W. Norde. (1996). Macromol. Symp. 103: 5-18.

W.F. Tan, L.K. Koopal, L.P. Weng, W.H. van Riemsdijk and W. Norde. (2008). Geochim. Cosmochim. Acta. 72: 2090-2099.

W.F. Tan, L.K. Koopal and W. Norde. (2008). Environ. Sci. Technol., submitted.

T. Arai and W. Norde. (1990). Colloids Surfaces 51:1-15.

W. Norde, T. Arai and H. Shirahama. (1991). Biofouling 4: 37-51.

C.A. Haynes and W. Norde.(1994). Colloids Surfaces B 2: 517-566.

B.W. Morrissey and R.R. Stromberg. (1974). J. Colloid Interace Sci. 46: 152-164.

P. Bagchi and S.M. Birnbaum. (1981). J. Colloid Interface Sci. 83: 460-478.

P.G. Koutsoukos, W. Norde and J. Lyklema. (1983). J. Colloid Interface Sci. 95: 385-397.

P. van Dulm, W. Norde and J. Lyklema. (1981). J. Colloid Interface Sci. 82: 77-82.

W. Norde and T. Zoungrana. (1998). Biotechnol. Appl. Biochem. 28: 133-143.

M.C.L. Maste, E.H.W. Pap, A. van Hoek, W. Norde and A.J.W.G. Visser. (1996). J. Colloid Interface Sci. 180: 632-633.

M.C.L. Maste, H.A. Rinia, C.J.M. Brands, M.R. Egmond and W. Norde. (1995). Biochim. Biophys. Acta 1252: 261-268.

S. Koutsopoulos, A.M. Tjeerdsma, J.F.T. Lieshout, J. van der Oost and W. Norde. (2005). Biomacromolecules 6: 1176-1184.

S. Koutsopoulos, J. van der Oost and W. Norde. (2005). Proteins, Structure, Function and Bioinformatics 61: 377-384.

A.W.P. Vermeer, W.H. van Riemsdijk and L.K.Koopal. (1998). Langmuir 14: 2810-2819.

C.J. Milne, D.G. Kinniburgh, W.H. van Riemsdijk and E. Tipping. (2003). Environ. Sci. Technol. 37: 958-971.

M. Ishiguro, W.F. Tan and L.K. Koopal. (2007). Colloids Surfaces A 159: 29-39.

F.J. Stevenson. (1994). In: Humus Chemistry; genesis, composition, reactions, $2^{\text {nd }}$ ed., John Wiley \& Sons Ltd. 